\title{
Limited migration of soluble ionic species in a Siple Dome, Antarctica, ice core
}

\author{
Karl J. Kreutz, Paul A. Mayewski, Sallie I. Whitlow, Mark S. Twickler \\ Climate Change Research Center, Institute for the Study of Earth, Oceans and Space, \\ and Department of Earth Sciences, University of New Hampshire, Durham, NH 03824, U.S.A.
}

\begin{abstract}
High-resolution $\left(>10\right.$ samples a $\left.^{-1}\right)$ glaciochemical analyses covering the last 110 years from a Siple Dome, Antarctica, ice core reveal limited migration of certain soluble ionic species (methane sulfonic acid, $\mathrm{NO}_{3}{ }^{-}$and $\mathrm{Mg}^{2+}$ ). The observed chemical migration may be due in part to seasonal alternation between less acidic winter (from high sea-salt concentrations) and more acidic summer (from high marine biogenic acid concentrations) layers, common at coastal sites such as Siple Dome. Exact mechanisms to explain the migration are unclear, although simple diffusion and gravitational movement are unlikely since new peaks are formed where none previously existed in each case. Initial migration of each species is both shallower and earlier at Siple Dome than at other sites in Antarctica where similar phenomena have been observed, which may be related to the relatively low accumulation rate at Siple Dome $\left(\sim 13.3 \mathrm{~cm}^{\text {ice a }}{ }^{-1}\right)$. Migration appears to be limited to either the preceding or following seasonal layer for each species, suggesting that paleoclimatic interpretations based on data with lower than annual resolution are not likely to be affected.
\end{abstract}

\section{INTRODUCTION}

Obtaining paleoatmospheric information on both regional and global scales is a key objective in ice-core research. The basis for such reconstructions is the fact that concentrations of chemical (and gaseous) species found in snow and ice are determined in part by the atmospheric concentrations of those species, and additionally by depositional and postdepositional processes. For certain soluble species (i.e. nonvolatile sea-salt and crustally derived ions), reconstruction of relative changes in paleoatmospheric concentrations is possible since post-depositional changes are negligible. For other species, such as $\mathrm{NO}_{3}{ }^{-}$and $\mathrm{H}_{2} \mathrm{O}_{2}$, both depositional and postdepositional processes in snow and ice can alter preserved concentrations of certain species, making interpretation of past atmospheric concentrations more difficult (Dibb, 1996). Post-depositional processes in most cases do not significantly alter long-term average concentrations, but can affect shortterm (i.e. sub-annual scale) fluctuations, as well as the amplitude and timing of chemical signal seasonality (Wolff, 1996).

An example of such a process is the recently observed post-depositional migration of methane sulfonic acid (MSA), an oxidation product of marine biogenically produced dimethyl sulfide (DMS) (Saltzman, 1995). A shift from summer (near the surface) to apparent winter (below $\sim 5-10 \mathrm{~m}$ depth) MSA deposition has been observed in Antarctic ice cores from Dolleman Island (Mulvaney and others, 1992), Byrd Station (Langway and others, 1994), the Filchner-Ronne Ice Shelf (FRIS; Minikin and others, 1994) and Berkner Island (Wagenbach and others, 1994). Because a change in the seasonal production and deposition of MSA is unlikely (Mulvaney and others, 1992), migration of MSA relative to excess (xs) $\mathrm{SO}_{4}{ }^{2-}$ (which continues to peak during $\delta^{18} \mathrm{O}$ maxima in the Dolleman Island core, and is therefore assumed to remain in place after summer deposition) is thought to have occurred. Interpretation of MSA/ $\mathrm{xsSO}_{4}{ }^{2-}$ molar ratios $(R)$ at these sites, especially where high-resolution sampling is performed $\left(>5\right.$ samples $\left.\mathrm{a}^{-1}\right)$, can be seriously complicated by post-depositional migration of MSA (Mulvaney and others, 1992). This phenomenon, however, has not yet been documented at enough sites to provide a clear spatial understanding of where and under what conditions it occurs.

Like MSA, post-depositional processes are known to affect $\mathrm{NO}_{3}{ }^{-}$concentrations in snow and ice. There is compelling evidence for $\mathrm{HNO}_{3}$ loss in surface snow at lowaccumulation-rate sites (Mayewski and Legrand, 1990; Dibb and Whitlow, 1996), possibly through photochemical degradation or degassing (Neubauer and Heumann, 1988). Diffusive smoothing of seasonal $\mathrm{NO}_{3}{ }^{-}$patterns in firn has also been noted (Wolff, 1996). Further, $\mathrm{NO}_{3}{ }^{-}$depletion has been observed in ice layers impacted by deposition of volcanically derived acids (mainly $\mathrm{H}_{2} \mathrm{SO}_{4}$ ) (Laj and others, 1993; Yang and others, 1996). While it is possible that changes in the atmospheric nitrogen cycle are responsible for decreased $\mathrm{NO}_{3}{ }^{-}$deposition during volcanic eruptions, an alternate explanation involves post-depositional migration of $\mathrm{NO}_{3}$ from the highly acidic volcanic-ice layers (Wolff, 1996). Clearly, the behavior of $\mathrm{NO}_{3}{ }^{-}$in acidic firn and ice layers needs to be understood so that proper interpretations of glaciochemical data can be made.

Chemical species derived from sea-salt aerosols $\left(\mathrm{Na}^{+}\right.$, $\mathrm{Cl}^{-}, \mathrm{Mg}^{2+}, \mathrm{K}^{+}, \mathrm{Ca}^{2+}$, which can be used as proxy indicators of past atmospheric circulation strength (e.g. Mayewski and others, 1994), are considered to be conservative, non-reactive, and therefore fixed in place after deposition in most locations. Wolff (1996), however, demonstrated that $\mathrm{Mg}^{2+}$ 
concentrations peak on either side of $\mathrm{Na}^{+}$winter maxima in the Dolleman Island ice core, causing disruption in standard $\mathrm{Mg}^{2+} / \mathrm{Na}^{+}$marine ratios. Although the migration of $\mathrm{Mg}^{2+}$ in the Dolleman Island core was confined within the same annual layer, paleoatmospheric circulation reconstructions based on multivariate statistical techniques (e.g. Mayewski and others, 1994) could potentially be affected by such migration. The problem may be enhanced in iceage ice (in both Antarctica and Greenland), where sea-salt concentrations can be $\sim 30-40$ times higher than modern values (Palais and Legrand, 1985). Dolleman Island is the only location so far where this phenomenon has been observed; therefore a more thorough investigation of the problem is needed to determine under what conditions it occurs.

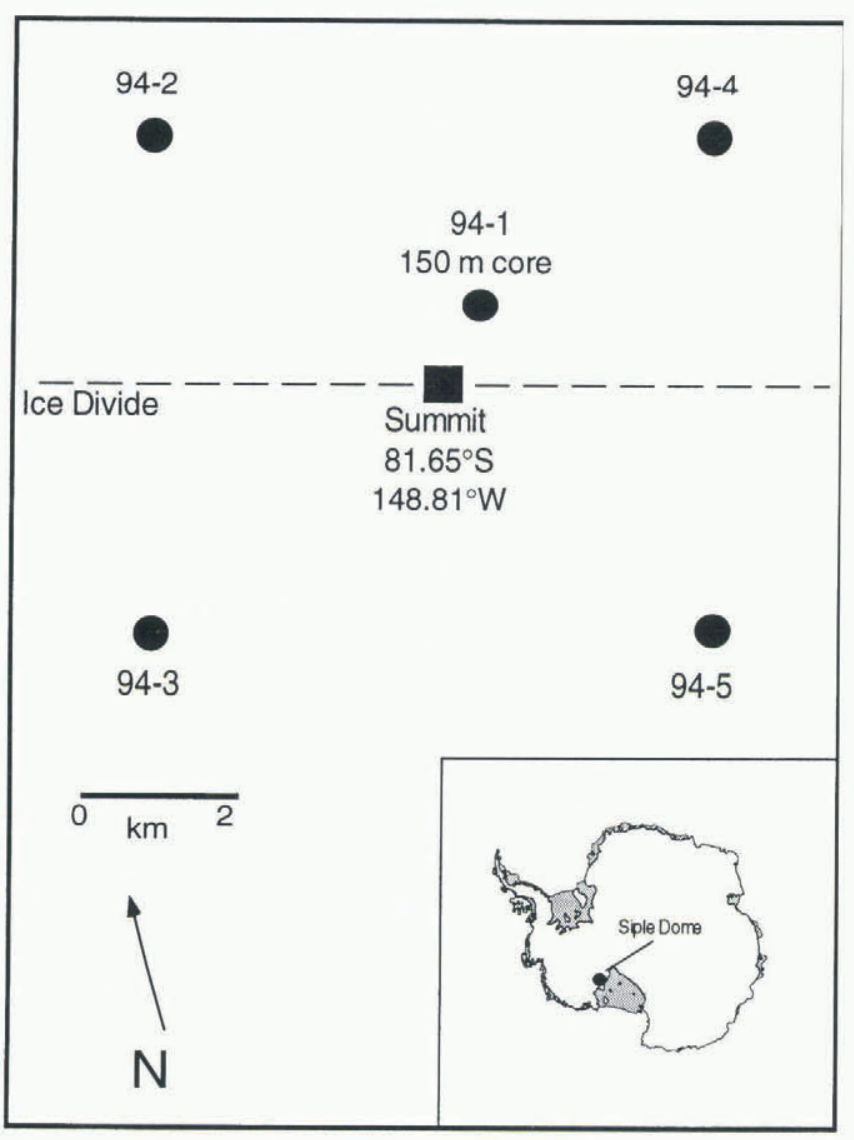

Fig. 1. Location map of 1994 sampling sites on Siple Dome, Antarctica. Pit 94-1 was sampled to $4 \mathrm{~m}$ depth, while pits $94-2,-3,-4$ and -5 were sampled to $2 m$ depth. Elevation of the Siple Dome summit is $621 \mathrm{~m}$.

In this paper, we present results from a Siple Dome, Antarctica $\left(81.65^{\circ} \mathrm{S}, 148.81^{\circ} \mathrm{W}\right.$; Fig. 1), ice-core glaciochemical record and investigate migration of the soluble chemical species described above. Compared to other sites where similar ion-migration phenomena have been observed, Siple Dome is unique in its high sea-salt and marine biogenic acid concentrations and relatively low accumulation rate $\left(\sim 13.3 \mathrm{~cm}\right.$ ice a ${ }^{-1}$; Kreutz and others, 1997). One result of these physical characteristics is a seasonal alternation between deposition of more acidic summer layers $\left(\mathrm{H}_{2} \mathrm{SO}_{4}\right.$, $\mathrm{HNO}_{3}$, MSA) and less acidic winter layers (sea salt). Because both sea-salt concentrations and accumulation rate have been suggested as possible controls on species migra- tion (Wolff, 1996), Siple Dome provides an ideal location to investigate these processes.

\section{METHODS}

During the 1994-95 field season, a $150 \mathrm{~m}$ core was drilled $\sim 3 \mathrm{~km}$ north-northeast of the summit of Siple Dome $(10 \mathrm{~m}$ temperature $-25^{\circ} \mathrm{C}$; Mayewski and others, 1995; Fig. 1). In addition, five snow pits were sampled in November 1994: a $4 \mathrm{~m}$ pit at the drill-site, and $2 \mathrm{~m}$ pits at each corner of a $10 \mathrm{~km} \times 10 \mathrm{~km}$ surveyed grid centered at the drill-site (Fig. 1). Snow-pit sampling and ice-core collection was performed by workers using non-particulating suits, polyethylene gloves, and particle masks. A $2 \mathrm{~cm}$ interval was used in snow-pit sampling.

Core samples were processed in a cold room at temperatures not exceeding $-12^{\circ} \mathrm{C}$, by individuals wearing pre-cleaned polyethylene gloves and particle masks. All tools and containers used were thoroughly pre-cleaned using ultra-pure water. The upper $2 \mathrm{~m}$ of core were not processed, due to poor core quality. As there is reasonable agreement between chemistry data from 2-4 $\mathrm{m}$ depth in the core and the $4 \mathrm{~m}$ core-site snow pit, the upper $2 \mathrm{~m}$ of pit 94-1 are used to create a continuous $24 \mathrm{~m}$ core record. Blanks of frozen ultra-pure water prepared at frequent intervals indicate that sample containers and techniques were free of contamination. Analysis of major cations $\left(\mathrm{Na}^{+}, \mathrm{K}^{+}\right.$, $\left.\mathrm{NH}_{4}{ }^{+}, \mathrm{Mg}^{2+}, \mathrm{Ca}^{2+}\right)$, anions $\left(\mathrm{Cl}^{-}, \mathrm{NO}_{3}{ }^{-}, \mathrm{SO}_{4}{ }^{2-}\right)$ and MSA in core and snow-pit samples was performed at the University of New Hampshire using Dionex 4000 series instruments. Cations were analyzed via suppressed chromatography with a Dionex CS12 column, $0.125 \mu$ l loop and $20 \mathrm{mM}$ MSA eluent. Anions were analyzed with a Dionex ASll column, $75 \mu \mathrm{l}$ loop and $6 \mathrm{mM} \mathrm{NaOH}$ eluent. MSA measurements were made with an ASll column, $1.5 \mathrm{ml}$ loop and $6 \mathrm{mM} \mathrm{NaOH}$ eluent.

Dating of the core and snow-pit samples was done using well-preserved annual chemical signals in both discrete and continuous melter sampling (notably $\mathrm{xsSO}_{4}{ }^{2-}$ (see below) and $\mathrm{Cl}^{-}$), beta radioactivity profiles, snow-pit and core stratigraphy, and volcanic marker horizons (Mayewski and others, 1995; Kreutz and others, 1997). Based on the depth/ age scale developed for the core, the 1150 year average accumulation rate is $\sim 13.3 \mathrm{~cm}_{\text {ice }} \mathrm{a}^{-1}$. The upper $24 \mathrm{~m}$ of the core was sampled at $2 \mathrm{~cm}$ intervals to provide a high-resolution (at least 8 samples $^{-1}$ ) glaciochemical record of the past 110 years.

Calculation of sea-salt (ss) and non-sea-salt (xs) portions of chemical species in Siple Dome snow-pit and core samples is based on bulk seawater ratios according to the formula (Delmas, 1992):

$$
\text { excess }=\text { total }-\left(\mathrm{Na}^{+} * k\right) \text {. }
$$

$\mathrm{Na}^{+}$is used as the reference species, as it was found to be the most conservative sea-salt element at Siple Dome (Kreutz and others, 1997). In the case of $\mathrm{SO}_{4}{ }^{2-}, \mathrm{xSSO}_{4}{ }^{2-}$ is the sum of (1) acidic sulfate and (2) the deficit (or excess) of $\mathrm{SO}_{4}{ }^{2-}$ in sea-salt aerosol (Mulvaney and Wolff, 1994). Using a $k$ value which reflects bulk seawater $\left[\mathrm{SO}_{4}{ }^{2}\right] /\left[\mathrm{Na}^{+}\right]$mass ratio $(0.252)$, calculations for winter snow and firn samples often lead to negative $\mathrm{xsSO}_{4}{ }^{2-}$ estimates at Siple Dome and other Antarctic coastal sites (Wagenbach and others, 1988; Gjessing, 1989; Mulvaney and others, 1992; Minikin and others, 1994). The deficit suggests that fractionation must be 
occurring between bulk seawater and sea-salt aerosol during parts of the year, but how such fractionation occurs is unclear. One possibility (Ducroz, 1996) is precipitation of $\mathrm{Na}_{2} \mathrm{SO}_{4}$ in seawater below $8^{\circ} \mathrm{C}$, resulting in a brine solution that is depleted in $\mathrm{SO}_{4}{ }^{2-}$ (the relative depletion of $\mathrm{Na}^{+}$ would be negligible since it is present in much higher concentrations). To correct for this problem, winter layers were separated for each snow pit and the upper $6 \mathrm{~m}$ of core. $\mathrm{SO}_{4}{ }^{2-}$ and $\mathrm{Na}^{+}$were plotted to calculate the slope $(k)$. Our results (Table 1) are similar to those obtained at other Antarctic sites. Therefore, we have used a $k$ value of 0.1 to calculate Siple Dome snow-pit and ice-core $\mathrm{xsSO}_{4}{ }^{2-}$ values. Because there is no evidence for $\mathrm{SO}_{4}{ }^{2-}$ fractionation during summer months, and our calculation is not seasonally dependent, summer $\mathrm{xsSO}_{4}{ }^{2-}$ values may be overestimated in some cases.

Table 1. Estimated sulfate to sodium mass ratio ( $k$ ) in seasalt aerosol at Siple Dome

\begin{tabular}{lccc}
\hline \multicolumn{1}{c}{ Location } & Sample type & $k$ & Source \\
\hline Siple Dome & & & \\
Core site & Snow and firn & 0.09 & This work \\
Pit 94-2 & Snow & 0.10 & This work \\
Pit 94-3 & Snow & 0.14 & This work \\
Pit 94-4 & Snow & 0.10 & This work \\
Pit 94-5 & Snow & 0.05 & This work \\
Mean & & 0.10 & This work \\
Bulk seawater & & 0.25 & Delmas (1992) \\
South Pole & Snow and firn & 0.12 & Harden (1996) \\
Dumont d'Urville & Snow and firn & 0.10 & Ducroz (1996) \\
FRIS & Snow and firn & 0.05 & Minikin and \\
& & & others (1994) \\
\hline
\end{tabular}

\section{RESULTS AND DISCUSSION}

\subsection{MSA}

MSA and $\mathrm{xSSO}_{4}{ }^{2-}$ concentrations from the upper $2 \mathrm{~m}$ of the Siple Dome core are presented in Figure 2. The two species are in phase through the upper $1.5 \mathrm{~m}$ (approximately 3.5 years). In addition, the last 3 years of $\mathrm{MSA}$ and $\mathrm{xsSO}_{4}{ }^{2-}$ maxima correspond with summer $\delta \mathrm{D}$ peaks. These findings are consistent with aerosol measurements at Neumayer Station, which are well correlated with the annual DMS cycle measured at the sub-Antarctic Macquairie Island (Gillet and others, 1993), suggesting that the three are directly related (Wagenbach, 1996). Likewise, $\mathrm{xsSO}_{4}{ }^{2-}$ and MSA concentrations in surface snow from coastal locations (FRIS (Minikin and others, 1994)) and inland locations (South Pole (Whitlow and others, 1992); Dronning Maud Land (Osada, 1994)) demonstrate strong seasonal signals that both peak in the summer. The $\mathrm{xsSO}_{4}{ }^{2} / \mathrm{MSA}$ relationship observed in the upper $1.5 \mathrm{~m}$ of the core (coeval existence in the first 3.5 years; not in depth due to small differences in accumulation rate between the north and south sides of the Siple Dome ice divide) is consistent in all Siple Dome snow pits collected in 1994 (Fig. 1).

Below $1.5 \mathrm{~m}$ in the core, MSA peaks occur slightly before (shallower than) $\mathrm{xsSO}_{4}{ }^{2-}$ peaks (Fig. 2). As previously discussed, we assume that this represents post-depositional migration of MSA and not a significant shift in deposition timing. This pattern (the first sign of MSA migration after the first 3 years) is spatially consistent over the $10 \mathrm{~km} \times$ $10 \mathrm{~km}$ grid on which six snow pits were collected (Fig. 1). Apparent initial migration of MSA at Siple Dome after 3 years is earlier than at Dolleman Island $(4.4 \mathrm{~m}$, or $\sim 5$ years; Mulvaney and others, 1992), Byrd Station (4.6 m, or 13 years; Langway and others, 1994), Berkner Island (3.5 $\mathrm{m}$, or $\sim 12$ years; Wagenbach and others, 1994) and the FRIS (1.8 m, or 8 years; Minikin and others, 1994).

Deeper in the core, $\mathrm{MSA}$ and $\mathrm{xSSO}_{4}{ }^{2-}$ peaks are clearly out of phase (Fig. 3). Specifically, below $2 \mathrm{~m}$ depth (selected $2 \mathrm{~m}$ sections of the core are presented in Figure 3), there is no place where MSA and $\mathrm{xsSO}_{4}{ }^{2-}$ are in phase. This situation is unlike Dolleman Island and Byrd Station cores, which contain a transition zone where the $\mathrm{MSA} / \mathrm{xsSO}_{4}{ }^{2-}$ relationship is both in and out of phase. At Siple Dome, MSA migration appears to occur early and without a transition zone. At least one MSA peak exists between each $\mathrm{xsSO}_{4}{ }^{2-}$ peak, suggesting that the distance of MSA migration must be limited to one season.
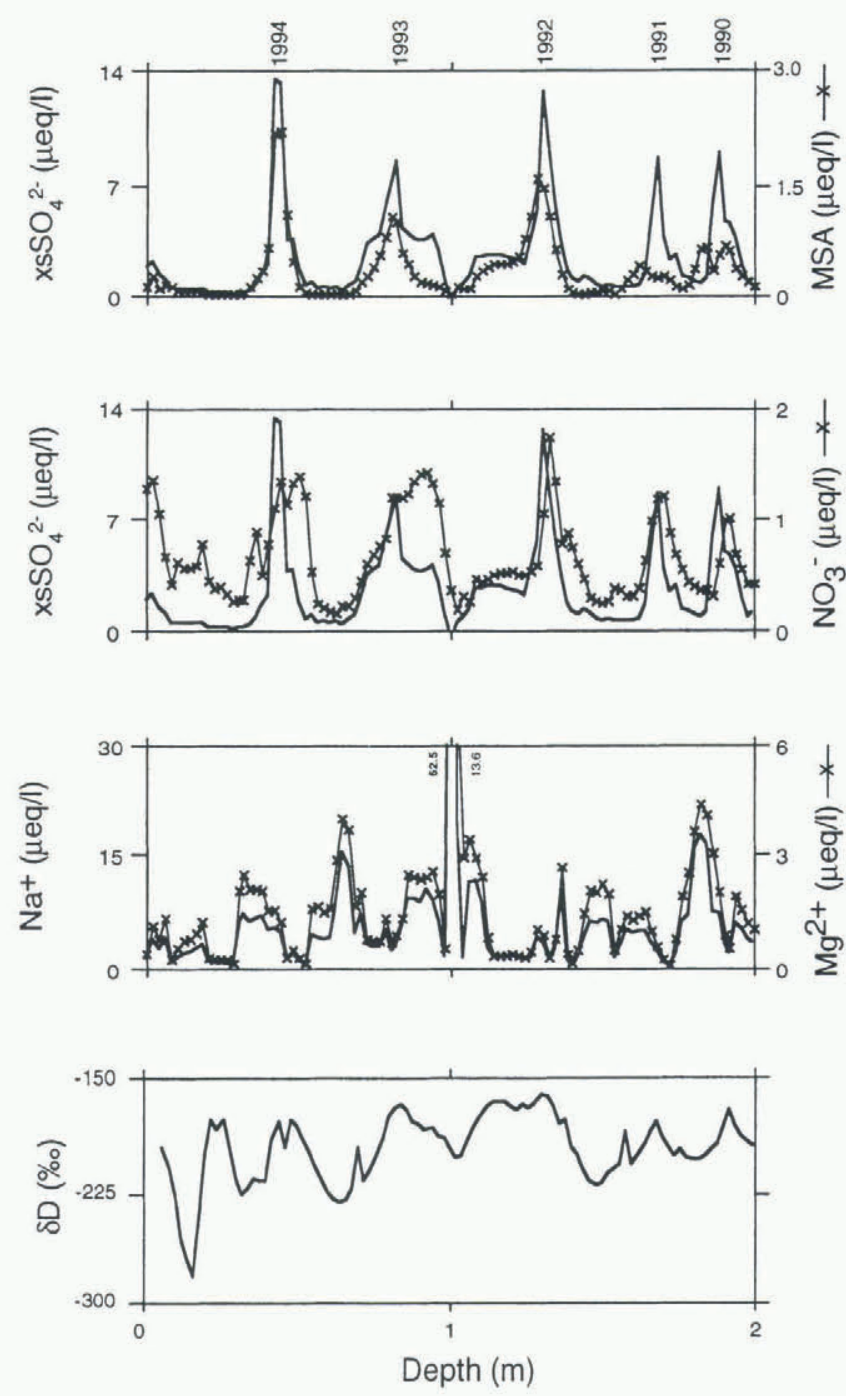

Fig. 2. Glaciochemical ( $\mu e q \Gamma^{-}$) and isotopic (per mil $(\%)$ ) concentrations in samples (2 $\mathrm{cm}$ sample interval) from the upper $2 \mathrm{~m}$ of Siple Dome snow. Approximately 5.5 years of snow deposition are contained in the $2 \mathrm{~m}$ section. Dates given above each plot represent 1 January of that year. 

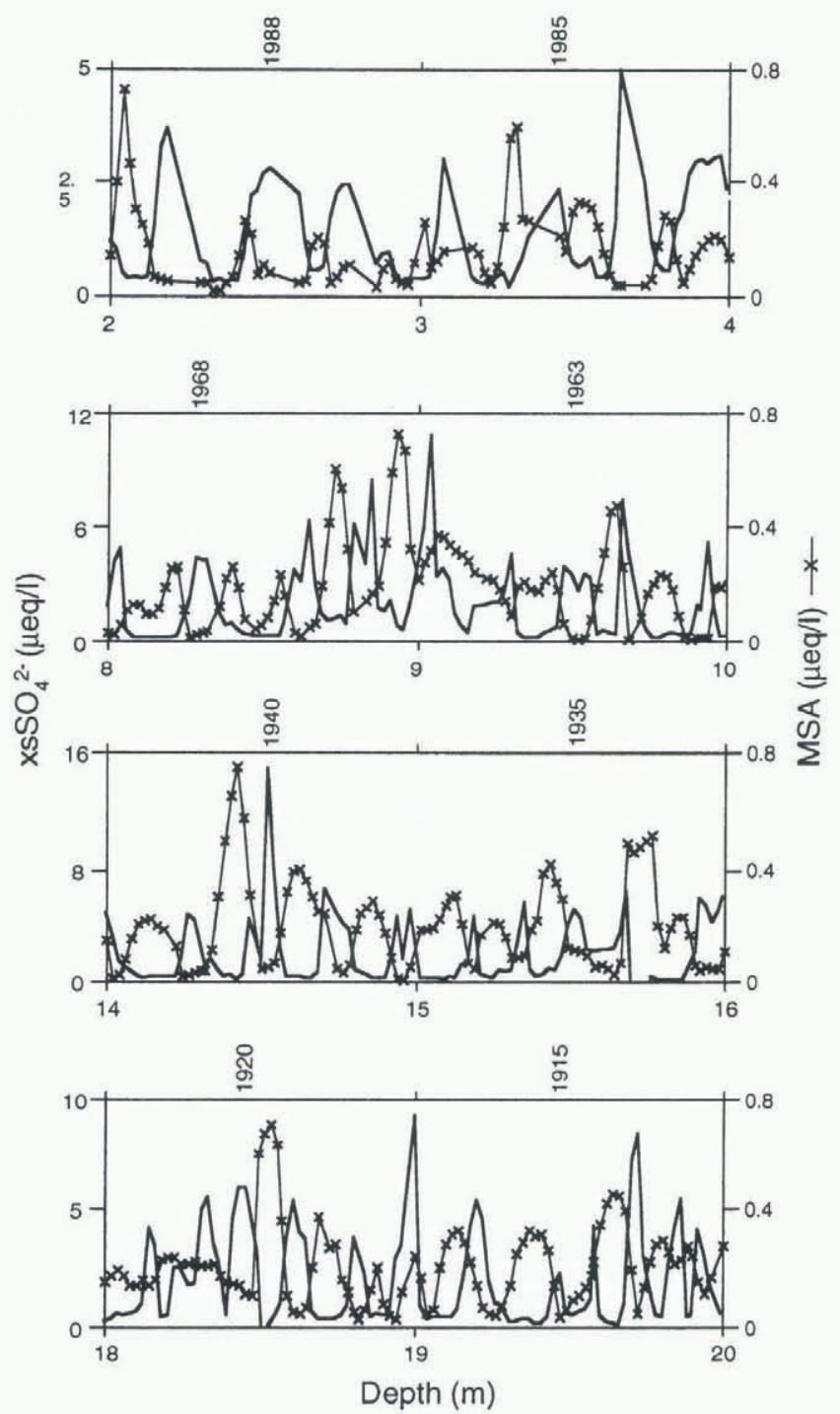

Fig. 3. $\mathrm{xsSO}_{4}^{2-}$ and MSA concentrations ( $\mu$ eq $\Gamma^{-1}$ ) in samples (2 cm sample interval) from four sections of the Siple Dome ice core. Corresponding dates are given above each plot.

Composite mean annual chemical cycles from different depths in the core (Fig. 4) also indicate MSA migration. Values of $\mathrm{xsSO}_{4}{ }^{2-}$ consistently peak during the austral summer in three different core sections. MSA values also indicate peak values during summer months in upper core samples. In the two lower sections, however, MSA values clearly have shifted to winter peaks. The apparent decrease in amplitude may be a function of fewer samples per year deeper in the core, and also the possible role of the prolonged early 1990s El Niño-Southern Oscillation (ENSO) event (Trenberth and Hoar, 1996) in producing very high MSA values in surface snow ( 1991-94). Although the reduction in amplitude would suggest diffusive smoothing of MSA, peak shapes appear to remain sharp and well defined throughout the upper $24 \mathrm{~m}$ (Fig. 3), and therefore the amount of diffusive smoothing must be limited.

\section{2. $\mathrm{NO}_{3}{ }^{-}$}

$\mathrm{NO}_{3}{ }^{-}$concentrations from the upper $2 \mathrm{~m}$ of the Siple Dome core are presented in Figure 2. Peak values of $\mathrm{NO}_{3}{ }^{-}$occur on the rising limb of $\delta \mathrm{D}$ cycles and slightly earlier than $\mathrm{xsSO}_{4}{ }^{2-}$ peaks (Fig. 2), suggesting that $\mathrm{NO}_{3}{ }^{-}$deposition occurs during late spring when the polar vortex initially breaks down. This is consistent with other observations of the annual $\mathrm{NO}_{3}{ }^{-}$cycle in Antarctic surface snow and air (Mayewski and Legrand, 1990; Savoie and others, 1992; Whitlow and others, 1992; Mulvaney and Wolff, 1993; Minikin and others, 1994; Osada, 1994; Wagenbach, 1996). This pattern (no apparent movement of $\mathrm{NO}_{3}{ }^{-}$relative to $\mathrm{xSSO}_{4}{ }^{2-}$ in the upper $2 \mathrm{~m}$ ) is spatially consistent over the $10 \mathrm{~km} \times$ $10 \mathrm{~km}$ grid on which five snow pits were collected. Unlike very low-accumulation-rate sites (i.e. South Pole, Vostok), Siple Dome gives no indication of significant $\mathrm{NO}_{3}{ }^{-}$enrichment in near-surface snow due to post-depositional degassing of $\mathrm{NO}_{3}^{-}$(Fig. 2).

In Figure 5, $\mathrm{NO}_{3}{ }^{-}$concentrations are plotted vs $\mathrm{xSSO}_{4}{ }^{2-}$ (summer indicator) for selected core sections in Figure 5. $\mathrm{NO}_{3}{ }^{-}$concentrations consistently peak slightly earlier than $\mathrm{xsSO}_{4}{ }^{2-}$ to a depth of $8.5 \mathrm{~m}$. In the $8.5-10 \mathrm{~m}$ section, the phase $\mathrm{NO}_{3}{ }^{-} / \mathrm{xsSO}_{4}{ }^{2-}$ relationship becomes confused. Below $10 \mathrm{~m}(10-12 \mathrm{~m})$, it appears that $\mathrm{NO}_{3}{ }^{-}$has migrated into the winter layer in some places, but is still in phase with $\mathrm{xsSO}_{4}{ }^{2-}$ in other places. By $14-16 \mathrm{~m}, \mathrm{NO}_{3}{ }^{-}$has clearly moved into winter layers during every annual cycle. Likewise, in the 18-20 m section, $\mathrm{NO}_{3}{ }^{-}$and $\mathrm{xsSO}_{4}{ }^{2-}$ are anticorrelated. In each core section, there is at least one $\mathrm{NO}_{3}{ }^{-}$peak for every $\mathrm{xsSO}_{4}{ }^{2-}$ peak, suggesting that the distance of $\mathrm{NO}_{3}{ }^{-}$migration must be limited to one season.
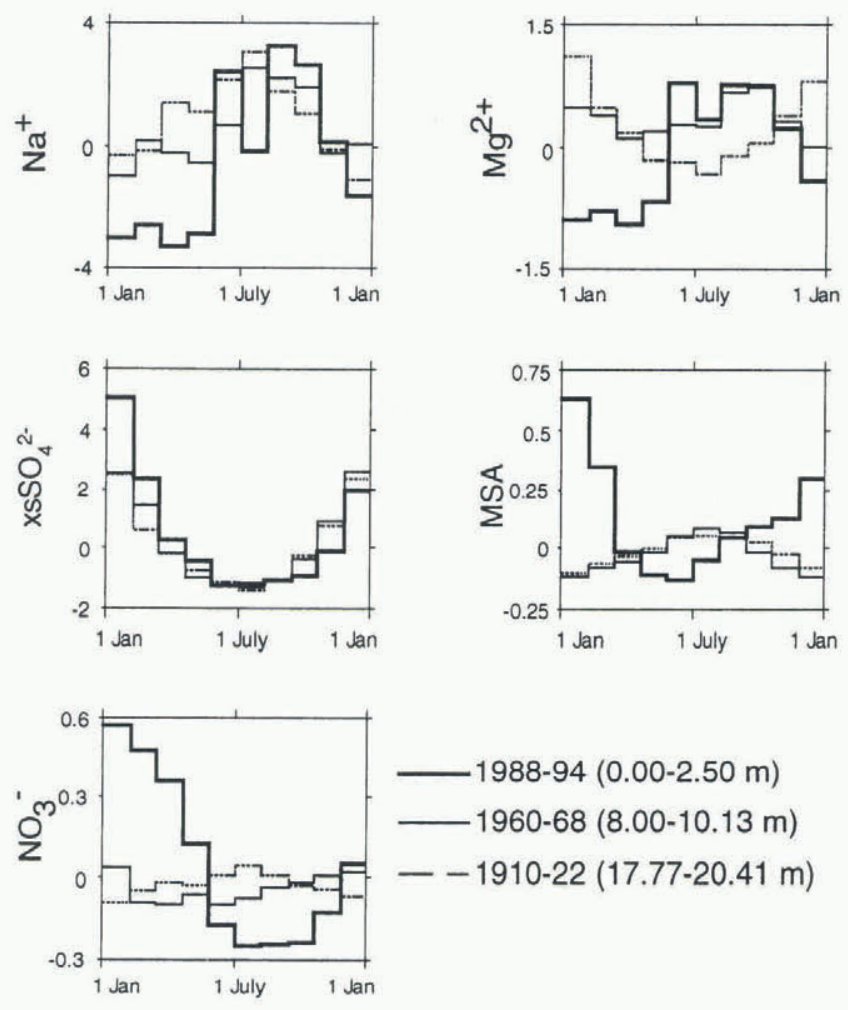

Fig. 4. Mean annual cycles of $\mathrm{Na}^{+}, \mathrm{Mg}^{2+}, x_{S} \mathrm{SO}_{4}{ }^{2-}, \mathrm{MSA}$, and $\mathrm{NO}_{3}{ }^{-}$in the upper $24 \mathrm{~m}$ of the Siple Dome core. Concentration values $\left(\mu e q \Gamma^{l}\right.$ ) are given as deviations from the 110 year mean of each species. The thick line corresponds to the near-surface depth interval, which overlaps snow-pit samples and the time interval (1988-94) of the prolonged early 1990s ENSO event, and contains the interval where MSA migration is first noted. The thin line represents the interval where $\mathrm{NO}_{3}^{-}$migration is first noted, and the thin dashed line is the interval where pronounced $\mathrm{Mg}^{2+}$ migration is observed. 


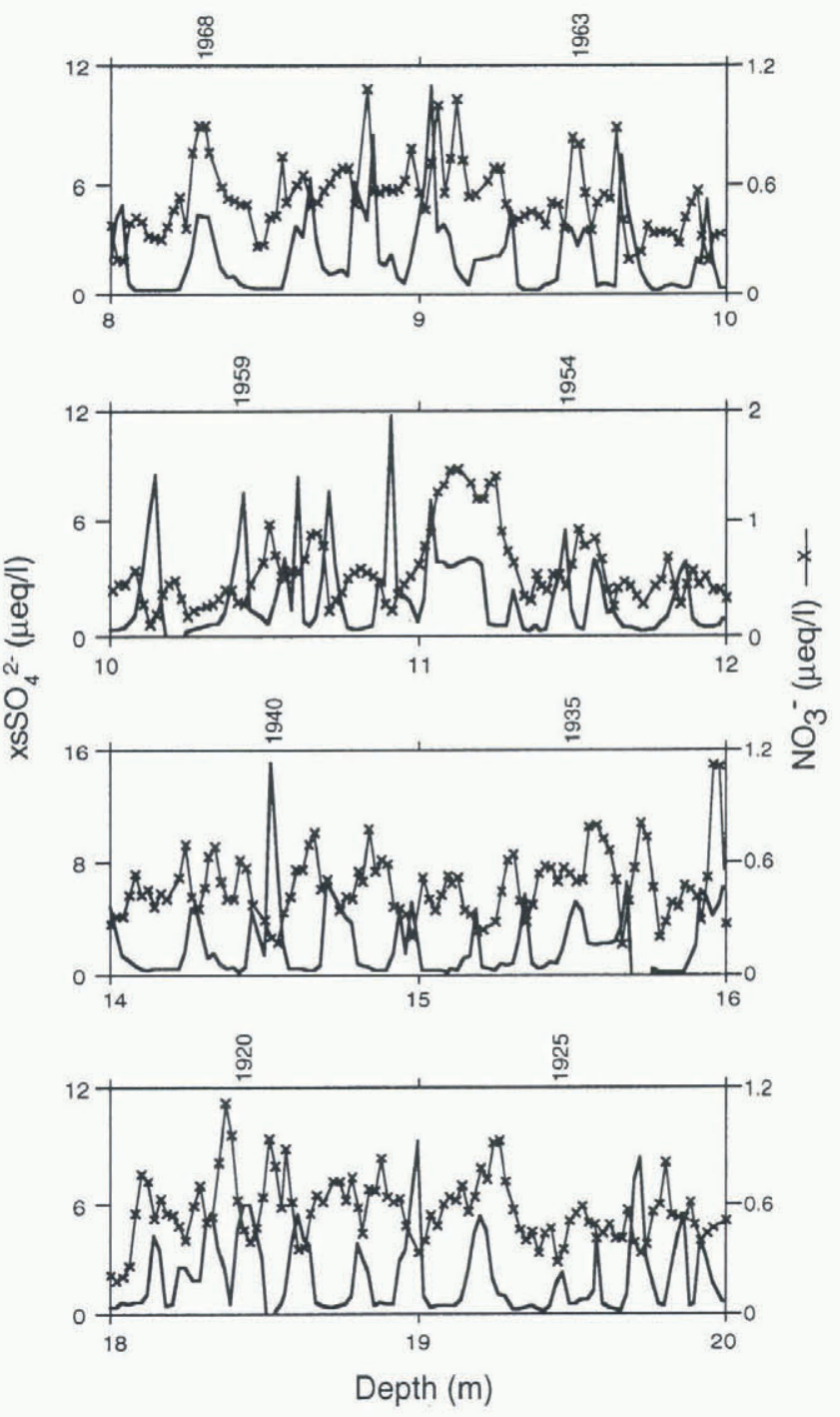

Fig. 5. $\mathrm{xSSO}_{4}{ }^{2-}$ and $\mathrm{NO}_{3}{ }^{-}$concentrations $\left(\mu e q \Gamma^{-1}\right.$ ) in samples ( $2 \mathrm{~cm}$ sample interval) from four sections of the Siple Dome ice core. Corresponding dates are given above each plot.

Composite mean annual $\mathrm{NO}_{3}{ }^{-}$values (Fig. 4) indicate summer peaks in upper core samples. In 1960-68 samples, there is still evidence of summer $\mathrm{NO}_{3}{ }^{-}$peaks, although the signal is much less pronounced than during 1988-94. In 1910-22 samples, $\mathrm{NO}_{3}{ }^{-}$values have shifted to winter peaks. There appears to be some loss of signal amplitude with increasing depth, which may be related to sampling and/or diffusive smoothing. The amount of diffusive smoothing occurring must be limited, as $\mathrm{NO}_{3}{ }^{-}$peaks retain a sharp character throughout the entire $24 \mathrm{~m}$ of detailed core data (Fig. 5).

\section{3. $\mathrm{Mg}^{2+}$}

$\mathrm{Mg}^{2+}$ concentrations in the upper $2 \mathrm{~m}$ of the Siple Dome ice core are presented in Figure 2. $\mathrm{Mg}^{2+}$ and $\mathrm{Na}^{+}$are well correlated (and in marine ratio), suggesting that $\mathrm{Mg}^{2+}$ at Siple Dome is mainly derived from sea-salt aerosol (Fig. 3). Peaks in $\mathrm{Mg}^{2+}$ and $\mathrm{Na}^{+}$generally occur during $\delta \mathrm{D}$ minima, indicating that most of the sea salt is deposited during winter. Aerosol measurements at Antarctic coastal stations (Neumayer (Wagenbach, 1996); Mawson (Savoie and others, 1992)) and inland stations (South Pole (Tuncel and others, 1989)), as well as surface snow measurements (Whitlow and others, 1992; Osada, 1994), also reveal a seasonal cycle in sea salt which peaks in the winter season. However, short-term sea-salt increases have also been observed throughout the year at Mawson and Neumayer stations, and are linked to local storm activity (Wagenbach, 1996). A similar situation is observed at Siple Dome, where input of sea salt occasionally occurs during summer (i.e. 1992, 1993). Because the seasalt cycle is out of phase with seasonal sea-ice fluctuations, transport of sea-salt aerosols during winter is most likely by rapid long-range advection from large open-water areas as well as from local polynias opened by heavy storm winds (Wagenbach, 1996). The correlation between $\mathrm{Na}^{+}$and $\mathrm{Mg}^{2+}$ is consistent in the top $2 \mathrm{~m}$ of other Siple Dome snow pits (Fig. 1).

The first indication of $\mathrm{Mg}^{2+}$ migration (relative to $\mathrm{Na}^{+}$) occurs at $9.65 \mathrm{~m}$ depth in the core, and is continued throughout the remaining $14 \mathrm{~m}$ of detailed data (Fig. 6). As in the Dolleman Island core (Wolff, 1996), migration of $\mathrm{Mg}^{2+}$ is characterized by $\mathrm{Mg}^{2+}$ peaks forming on either side of an $\mathrm{Na}^{+}$peak. The first indication of $\mathrm{Mg}^{2+}$ migration at Dolleman Island occurs below about $10 \mathrm{~m}$ (Wolff, 1996). Therefore, comparison of the problem in the two cores suggests that $\mathrm{Mg}^{2+}$ migration begins at a similar depth, but at different times ( $\sim 33$ years at Siple Dome; $\sim 13$ years at Dolleman Island). The lowest $\mathrm{Na}^{+}$concentration at which $\mathrm{Mg}^{2+}$ migration occurs at Siple Dome appears to be
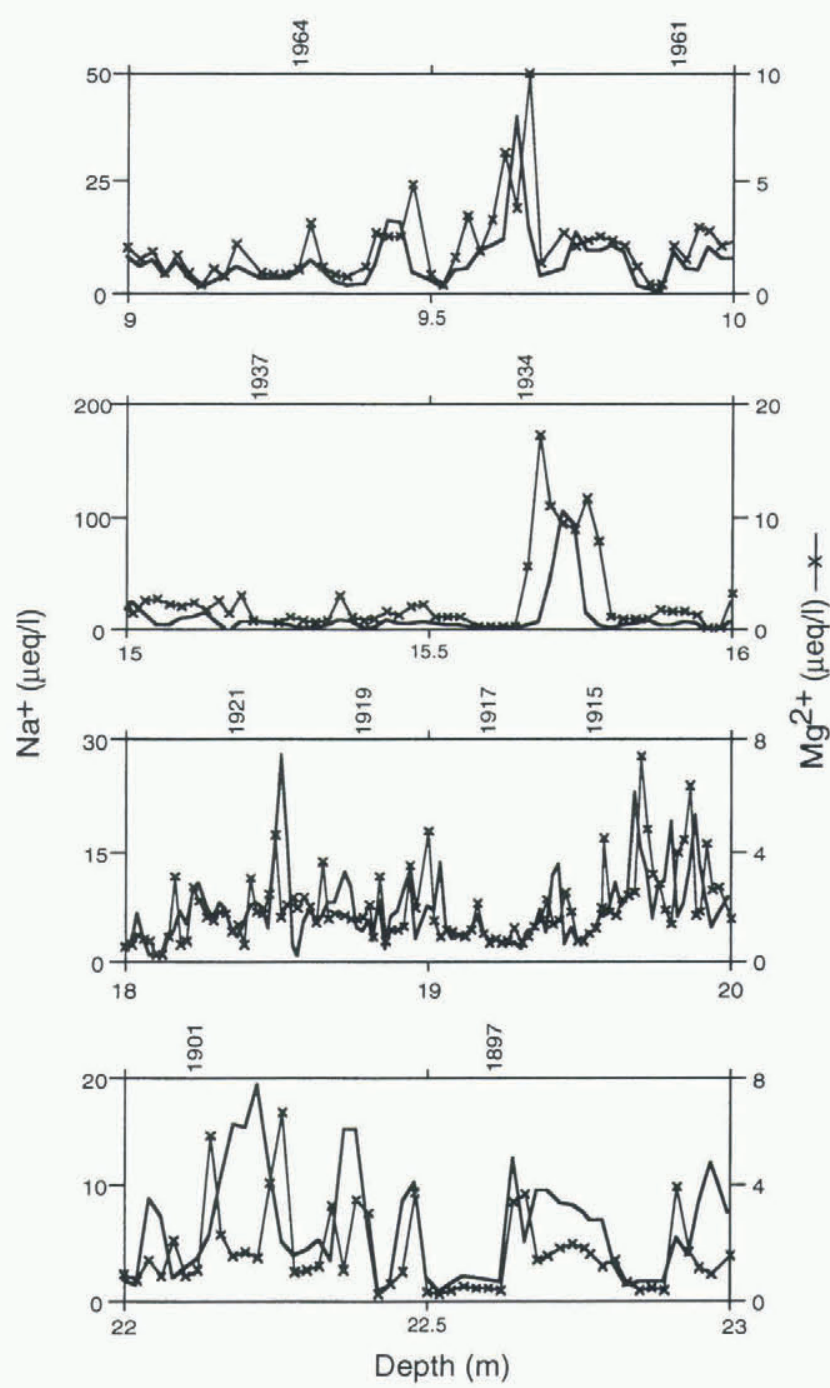

Fig. 6. $\mathrm{Na}^{+}$and $\mathrm{Mg}^{2+}$ concentrations ( $\mu$ eq ${ }^{-1}$ ) in samples (2 cm sample interval) from four sections of the Siple Dome ice core. Corresponding dates are given above each plot. 
$\sim 15 \mu \mathrm{eql} \mathrm{l}^{-1}$. Nearly every $\mathrm{Na}^{+}$peak above $15 \mu \mathrm{eql}^{-1}$ has $\mathrm{Mg}^{2+}$ peaks formed on either side. Based on limited data (39.6-42.5 m), a similar $\mathrm{Na}^{+}$threshold exists at Dolleman Island (Wolff, 1996).

Comparison of mean annual $\mathrm{Mg}^{2+}$ and $\mathrm{Na}^{+}$cycles (Fig. 4) indicates coeval winter peaks in upper core samples. In 1960-68 samples, there is still an identifiable winter $\mathrm{Mg}^{2+}$ peak, but it is weaker than in the upper part of the core. In 1910-22 samples, $\mathrm{Mg}^{2+}$ clearly peaks in the summer. This $2 \mathrm{~m}$ section of core (18-20 m; Fig. 6) contains a number of $\mathrm{Mg}^{2+}$ peaks that are directly out of phase with $\mathrm{Na}^{+}$. There is no apparent reduction in $\mathrm{Mg}^{2+}$ peak amplitude, and $\mathrm{Mg}^{2+}$ peaks retain a sharp character throughout all $24 \mathrm{~m}$ of high-resolution samples.

\subsection{Possible mechanisms for species migration}

Because summer $\left(\mathrm{xsSO}_{4}{ }^{2-}, \mathrm{NO}_{3}{ }^{-}\right.$and MSA) and sea-salt $\left(\mathrm{Na}^{+}\right.$and $\left.\mathrm{Mg}^{2+}\right)$ species are deposited in phase in the upper part of the core, we assume that the change in species relationship noted deeper in the core results from post-depositional migration and not a change in deposition timing. Several different mechanisms could be responsible for the observed migration: (1) diffusion (both vapour phase and within solid ice), (2) gravitational movement, (3) interactions within and outside the ice lattice, (4) migration associated with strongly acidic (i.e. volcanic) layers, and (5) formation of insoluble salts (Wolff, 1996).

For MSA, migration may be in the up-core direction where it is first noted $(1.5-2 \mathrm{~m}$ depth). This would rule out gravitational movement. Likewise, simple diffusion is unlikely, as peak shapes near the bottom of the detailed $24 \mathrm{~m}$ core section are still sharply defined, and new peaks have been formed where none previously existed. Wolff (1996) speculated that MSA may form an insoluble salt with one of the sea-salt cations, which would then allow continued diffusion, as the insoluble salt is a different species and would maintain the gradient. This process would effectively deplete the original peak, and form a new one in the sea-salt peak area, similar to what is observed at Siple Dome. The feasibility of this process is hard to assess since there is little information on the low-temperature solubility of MSA salts (Wolff, 1996). In addition, the freezing point of $\mathrm{Na}^{+}$or $\mathrm{Mg}^{2+}$ salts of MSA may be above the temperature of the ice, effectively removing MSA from the liquid phase. Again, there is little information on freezing-point curves for $\mathrm{Na}^{+}$or $\mathrm{Mg}^{2+}$ salts of MSA (Mulvaney and others, 1992). As the most pronounced MSA migration has been noted at sites with high sea-salt concentrations (Dolleman Island, FRIS, Siple Dome), it is imperative to understand the reactions between MSA and sea salts to determine if these are the main cause of migration. Another possibility is that MSA is located within veins at a eutectic composition, and therefore could move across an apparent gradient in bulk composition (Mulvaney and others, 1992). Eutectic compositions of strong acids commonly freeze below $0^{\circ} \mathrm{C}$, with many remaining liquid well below the temperature of Antarctic ice. This explanation, however, may not be effective in firn where ice grains have not compacted to form a completely interlinked network of veins, as in the upper $24 \mathrm{~m}$ of the Siple Dome core.

High summer biogenic $\mathrm{SO}_{4}{ }^{2-}$ concentrations in Siple Dome summer layers appear to have a significant effect on $\mathrm{NO}_{3}{ }^{-}$concentrations. The average summer $\mathrm{SO}_{4}{ }^{2-}$ maxi- mum in the upper $24 \mathrm{~m}\left(6.10 \mu \mathrm{eq}^{-1}\right)$ of the Siple Dome core is greater than all but the largest volcanic $\mathrm{SO}_{4}{ }^{2-}$ spikes (e.g. Tambora and AD 1259 events) recorded in Antarctic ice cores (Dai and others, 1991; Delmas and others, 1992; Langway and others, 1995) and Greenland ice cores (Laj and others, 1993) over the last 1000 years. $\mathrm{NO}_{3}{ }^{-}$migration from summer to winter layers is also seen (but not commented on) in Berkner Island (Wagenbach and others, 1994) and FRIS ice cores (Minikin and others, 1994), coastal sites with seasonal $\mathrm{SO}_{4}{ }^{2-}$ amplitudes comparable to Siple Dome's. At all three locations, $\mathrm{NO}_{3}{ }^{-}$migration appears to be limited to either the preceding or following winter layer, with peaks forming where none previously existed. Therefore, as with MSA, migration of both acids appears to be limited by winter layers with high sea-salt concentrations. Mechanisms to explain this phenomenon have not been studied in detail, but may include decreased sticking probability of the $\mathrm{HNO}_{3}$ molecule due to increased acidity (Laj and others, 1993). Constant $\mathrm{NO}_{3}{ }^{-}$migration (e.g. occurring every year below a certain depth) may be limited to coastal sites where there is alternation between more acidic summer and less acidic winter layers. Although we can provide no definite cause for $\mathrm{NO}_{3}{ }_{3}$ migration, it is clear that $\mathrm{NO}_{3}{ }^{-}$migration from volcanic layers cannot be ignored in the interpretation of changes in nitrogen atmospheric chemistry during volcanic periods.

The only other ice-core location where $\mathrm{Mg}^{2+}$ movement has been observed is Dolleman Island, where, as at Siple Dome, sea-salt concentrations are high (Dolleman Island: $\sim 12.6 \mu \mathrm{eql}^{-1} \mathrm{Na}^{+}, \sim 3.0 \mu \mathrm{eql}{ }^{-1} \mathrm{Mg}^{2+}$ (Mulvaney and others, 1992); Siple Dome: $\left.\sim 7.1 \mu \mathrm{eql}{ }^{-1} \mathrm{Na}^{+}, \sim 2.1 \mu \mathrm{eq} \mathrm{l}^{-1} \mathrm{Mg}^{2+}\right)$. The formation of two distinct peaks on either side of an $\mathrm{Na}^{+}$peak rules out simple diffusion, which would tend to smooth the record, and gravitational movement of a grain-boundary liquid. Wolff (1996) suggested that there may be a limited number of cation sites on grain boundaries, and that as the grain grows and surface area decreases, the number of sites may decrease. As sea-salt particles (initially present as discrete particles) slowly dissolve, $\mathrm{Na}^{+}$may preferentially occupy external sites, while $\mathrm{Mg}^{2+}$ is driven away from the high $\mathrm{Na}^{+}$and $\mathrm{Cl}^{-}$region (Wolff, 1996). This mechanism is speculative, and more work on this problem is clearly needed.

\subsection{Implications for core interpretation}

Migration of all three species discussed here appears to be limited to either the preceding or following seasonal layer. In the case of MSA and $\mathrm{NO}_{3}{ }^{-}$, migration is essentially stopped by the high concentration of sea salt in the winter layer. A similar pattern is observed for MSA at Dolleman Island, where migration continued at least until pore closeoff, but never went farther than one year (i.e. into the trough of the previous or following summer). In fact, deeper in the Dolleman Island core, MSA peaks became sharper, and summers became more and more depleted (Wolff, 1996). The maximum extent of $\mathrm{Mg}^{2+}$ migration appears to be one season, as with MSA and $\mathrm{NO}_{3}{ }^{-}$. In most cases, $\mathrm{Mg}^{2+}$ appears to migrate only to the shoulders of $\mathrm{Na}^{+}$peaks. Therefore, we would expect that interpretations based on data of greater than annual resolution will not be affected by $\mathrm{Mg}^{2+}$ migration.

To fully understand the observed chemical migration phenomena, two approaches are likely needed. First, con- 
tinued collection of samples from a wide variety of locations in Antarctica, such as those planned as part of the International Trans-Antarctic Scientific Expedition (Mayewski and Goodwin, 1996), will provide a more detailed spatial picture of the conditions under which these phenomena occur. Second, laboratory experiments are needed to investigate the small-scale interactions of chemical species and ice. For example, information on the exact location of impurities within the ice lattice and vapor-pressure effects would be useful in investigating species migration. While our results suggest that species migration is limited to less than one annual layer, an ultimate goal of ice-core paleoclimatic reconstructions is to make interpretations on sub-annual scales. To enable us to do so with long time-series ice-core glaciochemical records in areas where species migration occurs, our understanding of these problems must improve.

\section{ACKNOWLEDGEMENTS}

We thank Q. Yang for field assistance, J.W. C. White for isotopic data, R. Alley for stratigraphic measurements, the Polar Ice Coring Office (D. Giles and D. Kahler) for recovering the core, Navy SquadronVXE-6 and Antarctic Support Associates. This research was supported by the Office of Polar Programs, U.S. National Science Foundation.

\section{REFERENCES}

Dai, J., E. Mosley-Thompson and L.G. Thompson. 1991. Ice core evidence for an explosive tropical volcanic eruption 6 years preceding Tambora. 7. Geophys. Res., 96 (D9), 17,361-17,366.

Delmas, R. J. 1992. Environmental information from ice cores. Rev. Geophys., $30(1), 1-21$.

Delmas, R. J., S. Kirchner, J. M. Palais and J. R. Petit. 1992. 1000 years of explosive volcanism recorded at the South Pole. Tellus, 44B (4), 335-350.

Dibb, J. E. 1996. Overview of field data on the deposition of aerosolassociated species to the surface snow of polar glaciers, particularly recent work in Greenland. In Wolff, E. W. and R. C. Bales, eds. Chemical exchange between the atmosphere and polar snow. Berlin, etc., Springer-Verlag, 249-274. (NATO ASI Series I: Global Environmental Change 43.)

Dibb, J. E. and S. Whitlow. 1996. Recent climatic anomalies and their impact on snow chemistry at South Pole, 1987-1994. Geophys. Res. Lett., $23(10), 1115-1118$.

Ducroz, F. 1996. Étude de la composition chimique de la basse atmosphère des régions côtières Antarctiques. (Thèse de doctorat, Université Joseph Fourier-Grenoble I.

Gillet, R.W., G. P. Ayers, J. P. Ivery and J. L. Gras. 1993. Measurement of dimethylsulfide, sulfurdioxide, methanesulfonic acid and non sea salt sulfate at the Cape Grimm baseline station. In Restelli, G. and G. Angeletti, eds. Dimethylsulphide: oceans, atmosphere and climate (1992). Dordrecht, etc., Kluwer Academic Publishers, 117-128. (Air Pollution Research Report 43.).

Gjessing, Y.T. 1989. Excess and deficit of sulfate in polar snow. Almos. Environ., 18(1), 825-830.

Harder, S. 1996. Deposition of sulfate aerosol and isotopes of beryllium to the Antarctic snow surface and implications for ice cores and climate. (Ph.D. thesis, University of Washington.)

Kreutz, K. J., P. A. Mayewski, L. D. Meeker, M. S. Twickler, S. I. Whitlow and I. I. Pittalwala. 1997. Bipolar changes in atmospheric circulation during the Little Ice Age. Science, 277 (5330), 1294-1296.

Laj, P., J. M. Palais, J. E. Gardner and H. Sigurdsson. 1993. Modified $\mathrm{HNO}_{3}$ seasonality in volcanic layers of a polar ice core: snow-pack effect of photochemical perturbation? 7. Atmos. Chem., 16 (3), 219230.

Langway, C. C., Jr, K. Osada, H. B. Clausen, C. U. Hammer, H. Shoji and A. Mitani. 1994. New chemical stratigraphy over the last millennium for Byrd Station, Antarctica. Tellus, 46B (1), 40-51.

Langway, C. C., Jr, K. Osada, H. B. Clausen, C. U. Hammer and H. Shoji. 1995. A 10-century comparison of prominent bipolar volcanic events in ice cores. 7. Geophys. Res., 100 (D8), 16,241-16,247.

Mayewski, P. A. and I. D. Goodwin, comps. 1996. International Trans-Antarctic Scientific Expedition (ITA.SE). "200 years of past Antarctic climate and environmental change." Science and implementation plan, 1996. Report from the ITASE Workshop, Cambridge, United Kingdom, 2-3 August, 1996. Durham, NH, University of New Hampshire. (ITASE Workshop Report 97-I.)

Mayewski, P. A. and M. Legrand. 1990. Recent increase in nitrate concentration of Antarctic snow. Nature, 346 (6281), 258-260.

Mayewski, P. A. and 13 others. 1994. Changes in atmospheric circulation and ocean ice cover over the North Atlantic during the last 41,000 years. Science, 263 (5154), 1747-1751.

Mayewski, P. A., M. S. Twickler and S. I. Whitlow. 1995. The Siple Dome ice core-reconnaissance glaciochemistry. Antarct. J. U.S., 30 (5), 85-87.

Minikin, A., D. Wagenbach, W. Graf and J. Kipfstuhl. 1994. Spatial and seasonal variations of the snow chemistry at the central Filchner-Ronne Ice Shelf, Antarctica. Ann. Glaciol., 20, 283-290.

Mulvaney, R. and E.W. Wolff. 1994. Spatial variability of the major chemistry of the Antarctic ice sheet. Ann. Glaciol., 20,440-447.

Mulvaney, R., E. C. Pasteur, D. A. Peel, E. S. Saltzman and P. -Y. Whung. 1992. The ratio of MSA to non-sea-salt sulphate in Antarctic Peninsula ice cores. Tellus, 44B (4), 295-303.

Neubauer, J. and K. G. Heumann. 1988. Nitrate trace determinations in snow and firn core samples of ice shelves at the Weddell Sea, Antarctica. Atmos. Environ., $22(3), 537-545$.

Osada, K. 1994. Seasonal variations of major ionic concentration levels in drifting-snow samples obtained from east Dronning Maud Land, East Antarctica, Ann. Glaciol., 20, 226-230.

Palais, J. M. and M. Legrand. 1985. Soluble impurities in the Byrd Station ice core, Antarctica: their origin and sources. f. Geophys. Res., 90 (Cl), $1143-1154$.

Saltzman, E.S. 1995. Ocean/atmosphere cycling of dimethylsulfide. In Delmas, R. J., ed. Ice core studies of global biogeochemical cycles. Berlin, etc., Springer-Verlag, 65-90. (NATO ASI Series I: Global Environmental Change 30.)

Savoie, D. L., J. M. Prospero, R. J. Larsen and E. S. Saltzman. 1992. Nitrogen and sulfur species in aerosols at Mawson, Antarctica, and their relationship to natural radionuclides. 7. Atmos. Chem., 14, 181-204.

Trenberth, K. E. and T. J. Hoar. 1996. The 1990-1995 El Niño-Southern Oscillation event: longest on record. Geophys. Res. Lett., 23(1), 57-60.

Tuncel, G., N. K. Aras and W. H. Zoller. 1989. Temporal variations and sources of elements in the South Pole atmosphere. 1. Nonenriched and moderately enriched elements. J. Geophys. Res., 94 (D10), 13,025-13,038.

Wagenbach, D. 1996. Coastal Antarctica: atmospheric chemical composition and atmospheric transport. In Wolff, E.W. and R. C. Bales, eds. Chemical exchange between the atmosphere and polar snow. Berlin, etc., Springer-Verlag, 173-199. (NATO ASI Series I: Global Environmental Change 43.)

Wagenbach, D., U. Görlach, K. Moser and K. O. Münnich. 1988. Coastal Antarctic acrosol: the seasonal pattern of its chemical composition. Tellus, 40B (5), 426-436.

Wagenbach, D. and 6 others. 1994. Reconnaissance of chemical and isotopic firn properties on top of Berkner Island, Antarctica. Ann. Glaciol., 20, 307-312

Whitlow, S., P. A. Mayewski and J. E. Dibb. 1992. A comparison of major chemical species seasonal concentration and accumulation at the South Pole and Summit, Greenland. Atmos. Environ., 26A(11), 2045-2054.

Wolff, E.W. 1996. Location, movement and reactions of impurities in solid ice. In Wolff, E. W. and R. C. Bales, eds. Chemical exchange between the atmosphere and polar snow. Berlin, etc., Springer-Verlag, 541-560. (NATO ASI Series I: Global Environmental Change 43.)

Yang, Q., P. A. Mayewski, G. A. Zielinski, M. Twickler and K. C. Taylor. 1996. Depletion of atmospheric nitrate and chloride as a consequence of the Toba volcanic eruption. Geophys. Res. Lett., 23 (18), 2513-2516. 